\title{
Effects of Calcium Dobesilate on Colonic Anastomosis Healing: An Experimental Study
}

\section{Kalsiyum Dobesilatın Kolon Anastomoz İyileşmesi Üzerine Etkileri: Deneysel Bir Çalışma}

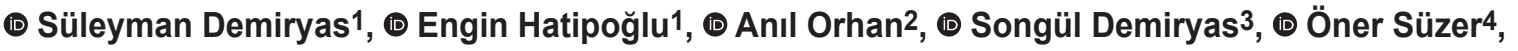

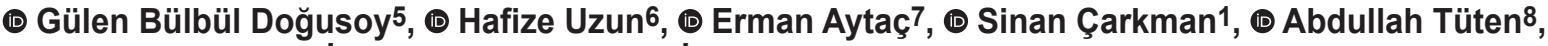 \\ (1) Ziya Salihoğlu9 ${ }^{9}$, (1) İhsan Taşçı1, (1) Turgut İpek10

\begin{abstract}
1İstanbul University-Cerrahpaşa, Cerrahpaşa Faculty of Medicine, Department of General Surgery, İstanbul, Turkey
2İnebolu State Hospital, Clinic of General Surgery, Kastamonu, Turkey

${ }^{3}$ Sofular Family Health Center, İstanbul, Turkey

${ }^{4}$ İstanbul University-Cerrahpaşa, Cerrahpaşa Faculty of Medicine, Department of Pharmacology, İstanbul, Turkey

${ }^{5}$ Gayrettepe Florence Nightingale Hospital, Clinic of Pathology, İstanbul, Turkey

${ }^{6}$ İstanbul University-Cerrahpaşa, Cerrahpaşa Faculty of Medicine, Department of Biochemistry, İstanbul, Turkey

${ }^{7}$ Mehmet Ali Aydınlar University Acıbadem Health Group Faculty of Medicine, Department of General Surgery, İstanbul, Turkey

8ístanbul University-Cerrahpaşa, Cerrahpaşa Faculty of Medicine, Department of Obstetrics and Gynaecology, İstanbul, Turkey

9ंstanbul University-Cerrahpaşa, Cerrahpaşa Faculty of Medicine, Department of Anesthesiology and Reanimation, İstanbul, Turkey

10Altınbaş University Faculty of Medicine, Department of General Surgery, İstanbul, Turkey
\end{abstract}

\section{|IIIIIII| ABSTRACT}

Aim: Anastomotic leakage in colon anastomosis (CA) increases morbidity and mortality. Calcium dobesilate (CaD) has angioprotective, antioxidant, lymphatic flow enhancing-and neuroprotective effects. Despite these capillary and cellular effects, there is no data in the literature regarding the effects of $\mathrm{CaD}$ on CA healing.

Method: Fifty Wistar-albino rats were randomly divided into five groups. All rats underwent CA after transverse colon transection. CaD was not administered to the control group (Group 1). CaD was administered to the experimental groups (Groups 2, 3, 4 and 5) intraperitoneally or by gavage at doses of 50 or $100 \mathrm{mg} / \mathrm{kg} / \mathrm{day}$. CaD was given as a single dose daily during postoperative five days. Bursting pressure values (BPV) and hydroxyproline values (HV) were measured. At the end of histopathological evaluation, polymorphonuclear leukocytes (PNLS), mononuclear leukocytes (MNLS), neovascularization (VS) and collagen fibers (CFS) were scored.

Results: CaD increased BPV and HV in experimental groups. We found a decrease in PNLS, MNLS, VS, and an increase in CFS in experimental groups. These increases seemed to be related to the administration doses of CaD. The decreases in PNLS, MNLS and VS were much more evident in Groups 4 and 5 than the other groups. There was no significant difference in terms of VS between experimental groups.

Conclusion: We found that CaD not only decreased the pathological parameters of inflammation, but also increased the strength of CA mechanically and biochemically. Although VS reduction seemed to have negative outcomes on CA, we know that CaD inhibits over-expression in angiogenesis. As a result, these effects of $\mathrm{CaD}$ appear to be dose-dependent rather than the administration methods.

Keywords: Calcium dobesilate, colon anastomosis, bursting pressure, hydroxyproline, antiangiogenesis, collagen fibers

\section{||||||||||| ÖZ}

Amaç: Kolon anastomozu (CA) sonrası gelişen anastomoz kaçağı morbidite ve mortaliteyi artırır. Kalsiyum dobesilate (CaD) anjiyoprotektif, antioksidan, lenfatik kan akımını artırıcı ve nöroprotektif etkilere sahiptir. Bu kapiller ve hücresel sahadaki etkilerine rağmen CaD’nin, CA iyileşmesi üzerine etkileri hakkında literatürde veri yoktur.

Address for Correspondence/Yazışma Adresi: Süleyman Demiryas MD,

İstanbul University-Cerrahpaşa, Cerrahpaşa Faculty of Medicine, Department of General Surgery, İstanbul, Turkey

Phone: +90 5423667232 E-mail: suleyman.demiryas@istanbul.edu.tr ORCID ID: orcid.org/0000-0002-0050-9099

Received/Gelis Tarihi: 18.08.2019 Accepted/Kabul Tarihi: 21.08.2019

${ }^{\odot}$ Copyright 2019 by Turkish Society of Colon and Rectal Surgery

Turkish Journal of Colorectal Disease published by Galenos Publishing House. 
Yöntem: Elli adet Wistar-albino sıçan, eşit sayıda ve rastlantısal olarak beş gruba ayrıldı. Tüm sıçanlara transvers kolon transeksiyonu sonrasında CA yapıld. Kontrol grubuna (Grup 1) CaD uygulanmadı. Deney gruplarına (Grup 2, 3, 4 ve 5), periton içi ya da gavajla ve 50 ya da 100 mg/kg/gün dozlarında $\mathrm{CaD}$ uygulandı. CaD, günlük tek doz ve ameliyat sonrası 5 gün verildi. Patlama basınç değerleri (BPV) ve hidroksiprolin değerleri (HV) ölçüldü. Sonunda histopatolojik değerlendirmede (HPE), polimorfonükleer lökositler (PNLS), mononükleer lökositler (MNLS), yeni damar oluşumu (VS) ve kollajen lifler (CFS) skorlandı.

Bulgular: Kalsiyum dobesilat, deney gruplarında BPV ve HV artırdı. Biz deney gruplarında PNLS, MNLS, VS'de azalma, CFS'de ise artış saptadık. Bu artış, ilacın uygulama dozu ile ilişkili gibi görünmektedir. Çalışma gruplarında HPE'de PNLS, MNLS ve VS azalmaktadır ama CFS artmaktadır. Grup 4, 5 PNLS, MNLS ve VS'lerinde saptanan azalma, diğer gruplardan belirgindi. Deney grupları arasında, VS açısından fark yoktu.

Sonuç: Biz, CaD’nin sadece patolojik olarak enflamasyon parametrelerini azaltmakla kalmadığını aynı zamanda mekanik ve biyokimyasal olarak CA'nın gücünü artırdığını saptadık. VS azalması, CA iyileşmesinde olumsuz sonuçlar doğuracak gibi görünmesine rağmen, biz CaD’nin angiogenesisde oversupresyonun inhibe ettiği biliyoruz. Sonuçta, CaD’nin bu etkileri, uygulama şeklinden ziyade doz bağımlı gibi görünmektedir.

Anahtar Kelimeler: Kalsiyum dobesilat, kolon anastomozu, patlama basincı, hidroksiprolin, antianjiogenezis, kollajen lifler

\section{Introduction}

Colon resection (CR) can be performed due to various emergency or elective pathologies. The anatomical integrity of gastrointestinal tract after resection is usually achieved by an anastomosis. Histologically, colonic anastomosis (CA) healing process can be divided into stages, and these stages of the healing in CA are substantially similar to the wound healing stages anywhere in the body. .,2,3,4,5,6,7,8 The most important factor in anastomotic healing is collagen, which constitutes the stretching force of submucosal connective tissue. ${ }^{9}$ The stage with highest risk for anastomotic leakage (AL) is the inflammation stage. ${ }^{3}$ AL following a CR is still considered a serious problem for surgical care and has an incidence between 3\% and 19\%.2,10 This estimate includes asymptomatic AL with an incidence as high as $50 \%{ }^{11}$ In case of AL, the duration of hospitalization is doubled and perioperative mortality is tripled compared to the normal healing process of CA. ${ }^{2}$ Many factors affect the healing of CA. ${ }^{2}$ Pre-operative colon mechanical cleansing, antibiotic prophylaxis, healthy tissue for anastomosis, surgical technique, indication for surgery (elective or emergency), radiotherapy, hypothermia, advanced age, presence of systemic diseases (obesity, jaundice, anemia, diabetes, chronic renal failure, cirrhosis, malignancies, etc.), nutritional status of the patient (malnutrition, alcoholism and smoking), immune status of the patient, medical prescriptions used by the patient, sepsis and shock are some of these factors. ${ }^{3,7,10,12,13,14,15}$ Calcium dobesilate (CaD) (Doxium $^{\circledR} 500 \mathrm{mg}$ capsule, Abdi İbrahim İlaç Sanayi ve Ticaret A.Ş, İstanbul, Turkey) is a synthetic agent, which has shown its efficacy at capillary level and which has vasoprotective effects. ${ }^{16,17,18,19,20}$ In the experimental studies, it has been shown that $\mathrm{CaD}$ has a neuroprotective activity and is an antiangiogenesis in diabetic neuropathy. ${ }^{21,22} \mathrm{CaD}$, reduces the over-expression of endothelin-1, intracellular adhesion molecule-1, vascular endothelial growth factor (VEGF) from retinal endothelial cells in diabetic retinopathy and prevents alterations on leukocyte adhesion. ${ }^{21,23} \mathrm{CaD}$ eliminates detrimental effects of reactive oxygen species (ROS). ${ }^{24,25,26} \mathrm{CaD}$ increases the nitric oxide synthase activity of capillary endothelial cells and regulates the formation of basal membrane collagen network. ${ }^{16,19,25}$ It also regulates the capillary membrane resistance that reduces capillary hyperpermeability and fragility. ${ }^{18,27}$ It reduces platelet aggregation and prevents thrombus formation. ${ }^{25,28,29}$ Moreover, it also inhibits hyaluronidase, which is responsible for the fragmentation of the matrix mucopolysaccharides in the capillary basal membrane. ${ }^{16,18,30} \mathrm{CaD}$ reduces transcapillary escape of albumin from peripheral circulation. ${ }^{18}$ The antioxidant properties of $\mathrm{CaD}$ are attributed to its scavenger activity in lipid peroxidation caused by ROS. It also inhibits the release of inflammatory cytokines, such as platelet activating factor (PAF). ${ }^{17}$ Notwithstanding these capillary and cellular effects, there is no data available in the current literature regarding the effects of $\mathrm{CaD}$ on healing of $\mathrm{CA}$.

\section{Materials and Methods}

\section{Animal Model and Treatment Protocol}

The current study was performed using 10-12 week-old male Wistar rats $(n=50)$ weighing $225 \pm 25 \mathrm{~g}$. The rats were housed in a temperature-controlled room (20-22 ${ }^{\circ} \mathrm{C}$ ) and $55-60 \%$ humidity with 12 -h light-dark cycles. All rats were fed a standard rodent chow (20\% protein, $6 \%$ cellulose, $2 \%$ fat in $100 \mathrm{~g}$ of chow) and given water ad libitum. After an adaptation period of one week, the experimental animals were randomly divided into four experimental groups as Groups 2, 3, 4 and 5, and one control group as Group 1. The treatments were as follows: only CA was performed in Group $1(\mathrm{n}=10)$; CA was performed and $\mathrm{CaD}$ was administered intraperitoneally $50 \mathrm{mg} / \mathrm{kg} /$ day in Group 2 ( $\mathrm{n}=10)$; CA was performed and $\mathrm{CaD}$ was administered by gavage at a dose of $50 \mathrm{mg} / \mathrm{kg} /$ day in Group $3(\mathrm{n}=10)$; CA was performed and $\mathrm{CaD}$ was administered intraperitoneally $100 \mathrm{mg} / \mathrm{kg} /$ day in Group $4(n=10)$ and CA was performed and $\mathrm{CaD}$ was administered by gavage at a dose of $100 \mathrm{mg} / \mathrm{kg} /$ day in Group 
5. The design of the experimental groups and control group is shown in Figure 1. An excipient of $0.9 \%$ sodium chloride was used for the preparation of various concentrations of $\mathrm{CaD}$ for intraperitoneal applications and distillated water was used as the adjuvant for various concentrations of $\mathrm{CaD}$ for gavage applications. After 12 hours post-operatively, $\mathrm{CaD}$ was administered to the experimental Groups 2, 3, 4 and 5) for five days (Figure 1). All experimental studies were conducted in accordance with the National Institutes of Health guide for the care and use of laboratory animals (NIH Publications No. 8023, revised in 1978). The ethical protocol of the current research was approved by Ethics Committee of İstanbul University, İstanbul, Turkey. Institutional Review Board (IRB) (number: 2006/ 30826).

\section{Surgical Procedure}

The rats were anesthetized by an intramuscular injection of ketamine hydrochloric acid (HCL) $50 \mathrm{mg} / \mathrm{kg}$ (Ketalar ${ }^{\circledR}$, Eczacıbaşı Pharmaceuticals Marketing, Lüleburgaz, Turkey) and xylazine HCL $10 \mathrm{mg} / \mathrm{kg}$ (Rompun ${ }^{\circledR} \%$, Bayer, Leverkuesen, Germany). We made a midline incision to expose the transverse colon, which was divided about midway. Integrity was restored with an inverted one-layer end-to-end anastomosis consisting of six or eight interrupted sutures of 6/0 polypropylene (Prolene ${ }^{\circledR}$; Ethicon, İstanbul, Turkey). The abdomen was closed in two layers with a continuous $3 / 0$ silk suture for the fascia and skin. All rats underwent re-laparotomy at the end of the $5^{\text {th }}$ day and all of them were sacrificed with high-dose ether anesthesia.

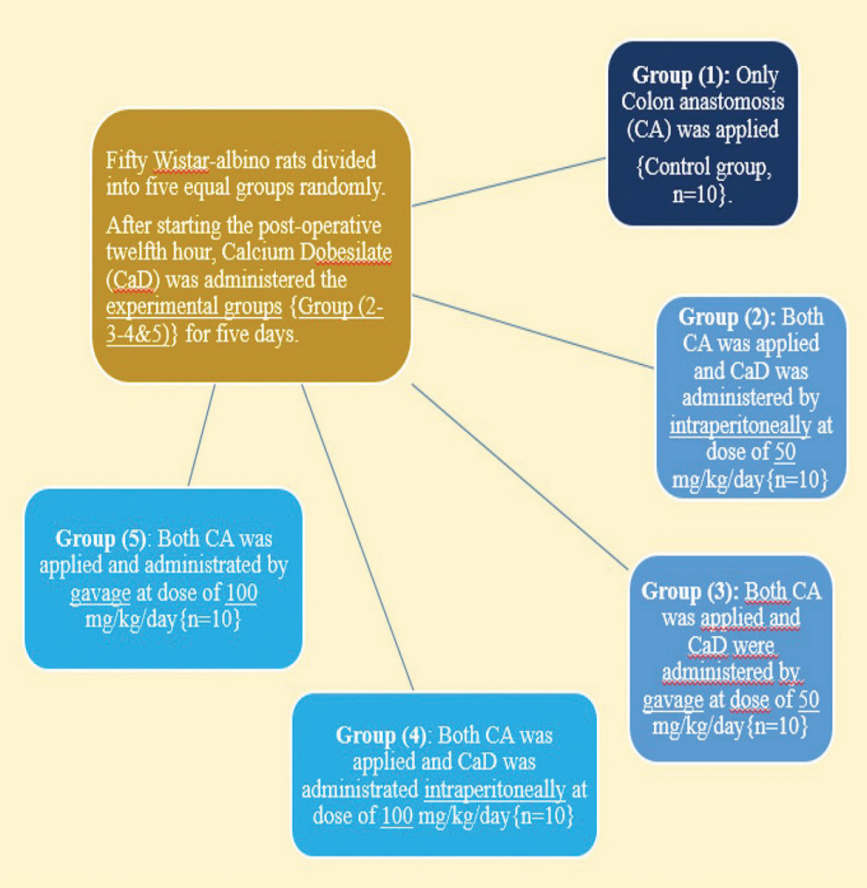

Figure 1. Design of the experimental groups and control group CA: Colon anastomosis, CaD: Calcium dobesilate

\section{Bursting Pressure Measurements}

Bursting pressure value (BPV) was measured ex vivo. After re-laparotomy on the fifth postoperative day, anastomotic colonic segments were resected and bursting pressures were measured. The distal end of colon was ligated using a 3/0 silk suture and a catheter was secured into the proximal end and fixed to the bursting pressure apparatus as described elsewhere. ${ }^{3,31}$ Through this catheter, the bowel was infused with a continuous flow of air at a rate of $3 \mathrm{~mL} / \mathrm{min}$ using an infusion pump [Perfuser E (type 871112), B. Braun Meisingen a 6 device]. BPV was defined as the value recorded at the point of an air leakage or gross rupture, and it was noted in mmHg. The site of leakage or rupture during the bursting pressure measurement occurred at the anastomosis area in all rats.

\section{Preparation of Tissue Homogenates}

After anastomotic BPV measurement, one centimeter of the colonic segment including the anastomosis site was resected from each subject and half of the specimen was fixated in $10 \%$ formaldehyde for histopathological examination. The other half was used in tissue homogenate extraction to determine hydroxyproline levels (HV). The extracted tissues were rinsed in ice-cold PBS $(0.02 \mathrm{~mol} / \mathrm{L}, \mathrm{pH}$ 7.07.2) to remove excess blood thoroughly and weighed before homogenization. Tissues were minced and homogenized in $6 \mathrm{~N}$ HCL. The homogenates were then centrifuged at 1.500 x g (or $5.000 \mathrm{rpm}$ ) for 15 minutes. Removed supernatant samples were stored at -20 to $-80^{\circ} \mathrm{C}$ until the assay time for hydroxyproline.

\section{Estimation of Tissue Hydroxyproline Concentrations}

The chemicals used for the hydroxyproline assay were of the highest analytical grade available. All of the chemicals were purchased from Sigma-Aldrich (St Louis, MO, USA). All reagents were stored at $+4{ }^{\circ} \mathrm{C}$ and brought to room temperature 20 minutes prior to the usage. Tissue HV were assessed by using the Bergman \& Loxley method. ${ }^{32}$ The analytic principle of the assay was colorimetric measurement of the colored complex formed with p-dimethylaminobenzaldehyde of pyrrolle after the oxidation of hydroxyl pyroline to pyrrole compound with chloramine T using a spectrophotometer (Shimadzu UV 1601, Tokyo, Japan) at $560 \mathrm{~nm}$. The absorbance of trans-4hydroxy-L-proline standards was used for the standard curve drawing. Hydroxyproline concentrations were expressed as $\mathrm{mg} / \mathrm{g}$ of tissue-wet weight.

\section{Histopathological Evaluation}

After the samples fixed in $10 \%$ formalin solution for 24 hours, they were processed with standard paraffin technique and stained with hematoxylin and eosin. The samples were 
then examined under a light microscope. The parameters were evaluated with help of the modified Ehrlich \& Hunt scoring scale including polymorphonucleated cells (PNL), mononuclear cells (MNL), neovascularization and collagen fibers $(\mathrm{CF})$. Scores ranged from 0 to 4 as: score $0(-)=$ no evidence, score $1(+)=$ occasional evidence, score $2(++)=$ light scattering, score $3(+++)=$ abundant evidence, and score 4 $(++++)=$ confluent fibers or cells. ${ }^{9,33,34,35}$

\section{Statistical Analysis}

Categorical variables were presented in percentages and continuous variables were expressed as mean \pm standard deviation. Repeated measures ANOVA, Post-hoc tests, Tukey-Kramer test and chi-square test were used to analyze statistical differences between the groups regarding BPV, $\mathrm{HV}$ and histopathological evaluation. A p value less than 0.05 was considered significant.

\section{Results}

\section{Bursting Pressure Values}

Anastomotic BPVs of Group 2 and 3 were significantly higher compared to Group 1 ( $\mathrm{p}<0.05)$. There was no significant difference between Group 2 and 3 in terms of BPV (Figure 2). BPVs of Group 4 and 5 were significantly higher compared to Group 1, 2 and 3 (p<0.05). The comparison between Group 4 and Group 5 showed no significant difference (Figure 2). Table 1 shows anastomotic BPVs (mmHg) and HV (mg/g) according to groups.

\section{Hydroxyproline Values}

HVs of Group 2 and 3 were significantly higher compared to Group $1 \quad(\mathrm{p}<0.05)$. There was no significant difference between Group 2 and 3 in terms of HV (Figure 3). HV of Group 4 and 5 were significantly increased when compared to Group 1, 2 and 3 ( $\mathrm{p}<0.05)$. The comparison between Group 4 and Group 5 showed no significant difference (Figure 3).

\section{Histopathological Evaluation}

\section{Polymorphonuclear Leukocyte Infiltration Scores (PNLS)}

Group 1 showed a significant increase in scores 2 and 3 $(\mathrm{p}<0.05)$. There was no statistically significant difference between Group 1, Group 2 and Group 3 (p>0.05). Group 4 and 5 showed a significant increase in scores 1 and 2 $(\mathrm{p}<0.05)$. The increase in score 1 in Group 4 and 5 was statistically significant compared to other groups $(\mathrm{p}<0.05)$.

\section{Mononuclear Leukocyte Infiltration Scores (MNLS)}

Group 1 showed a significant increase in score 2 ( $\mathrm{p}<0.05)$. Group 2 and Group 3 had a significant increase in score 1 when compared to Group $1 \quad(\mathrm{p}<0.05)$. There was no statistically significant difference between Group 2 and
Group 3 ( $p>0.05$ ). Group 4 and Group 5 showed a significant increase in score 1 compared to Group 1 ( $\mathrm{p}<0.05)$. Groups 1 , 2,3 and 5 showed a significant increase in score 2 compared to Group $4(\mathrm{p}<0.05)$.

\section{Neovascularization Scores (VS)}

Groups 1, 2 and 4 did not show any statistically significant difference when compared to each other $(p>0.05)$. When

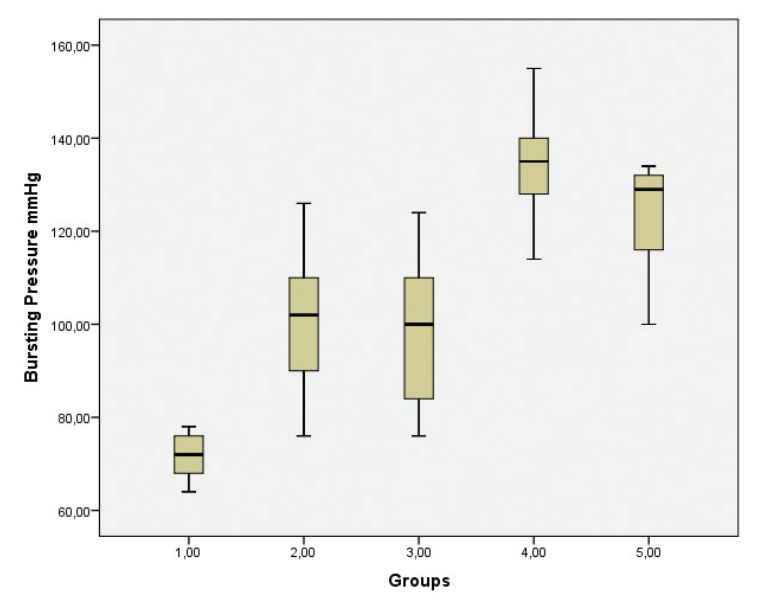

Figure 2. The mean burst pressure values of the groups

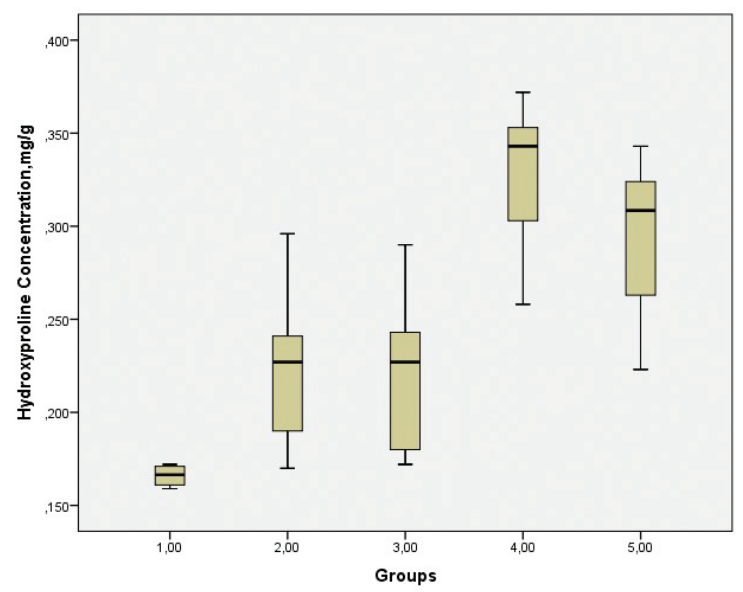

Figure 3. The mean tissue hydroxyproline levels of the groups

Table 1. Burst pressure values and tissue hydroxyproline values of all groups (mean \pm standard deviation)

\begin{tabular}{lll} 
& BPV $(\mathrm{mmHg})$ & HV $(\mathrm{mg} / \mathrm{g})$ \\
\hline Group $1(\mathrm{n}=10)$ & $71.6 \pm 4.6$ & $0.166 \pm 0.004$ \\
Group 2 $(\mathrm{n}=10)$ & $100.6 \pm 15.2$ & $0.222 \pm 0.036$ \\
Group 3 $(\mathrm{n}=10)$ & $97.6 \pm 15.3$ & $0.218 \pm 0.038$ \\
Group 4 $(\mathrm{n}=10)$ & $135.1 \pm 11.6$ & $0.329 \pm 0.035$ \\
Group 5 $(\mathrm{n}=10)$ & $123.8 \pm 10.7$ & $0.295 \pm 0.039$
\end{tabular}

BPV: Burst pressure values, HV: Hydroxyproline values 
Table 2. Histopathological scores of the groups

$\begin{array}{lllll} & \text { PNLS } & \text { MNLS } & \text { VS } & \text { CFS } \\ \text { Group 1 } & +++/++ & ++ & ++/+++/+ & ++/+ \\ \text { Group 2 } & +++/++ & ++/+ & +/++/+++ & ++ \\ \text { Group 3 } & ++/+++ & +/++ & ++ & ++ \\ \text { Group 4 } & +++/++/+ & + & ++/+++/ & ++ \\ \text { Group 5 } & ++/+ & +/++ & +/++ & ++\end{array}$

PNLS: Polymorphonuclear leukocyte score, MNLS: Mononuclear leukocyte score, VS: Neovascularization score, CFS: Collagen fiber score

Groups 1, 2 and 4 were compared with Group 3, the increase in scores 1 and 3 were statistically significant $(\mathrm{p}<0.05)$. When Groups 1, 2 and 4 were compared with Group 5, the increase in score 3 was statistically significant $(\mathrm{p}<0.05)$. Group 5 showed a significant increase in scores 1 and 2 compared to Group 3 ( $\mathrm{p}<0.05)$.

\section{Collagen Fiber Scores (CFS)}

Group 1 showed a statistically significant increase in scores 1 and $2(p<0.05)$. Groups 2, 3, 4 and 5 had a significant increase in score $2(\mathrm{p}<0.05)$. When Group 1 was compared to Groups 2, 3, 4 and 5, the increase in score 1 was statistically significant $(\mathrm{p}<0.05)$. Groups 2, 3, 4 and 5 did not show a statistically significant difference when compared to each other ( $p>0.05)$. Table 2 shows the distribution and comparison of statistically significant scores according to groups.

\section{Discussion}

It has been shown that $\mathrm{CaD}$ not only has inhibitor activity on VEGF production, but also improves microvascular hemodynamics and shows anti-leakage effects by reducing plasma endothelin-1 levels in experimental diabetic retinopathy. ${ }^{21,23}$ Despite its antioxidant and antiinflammatory effects, studies investigating the effects of $\mathrm{CaD}$ on wound healing are limited. Eventually, no studies have investigated the therapeutic efficacy of $\mathrm{CaD}$ on colon anastomosis healing. It has been previously reported that $\mathrm{CaD}$ inhibits platelet aggregation and prevents thrombus

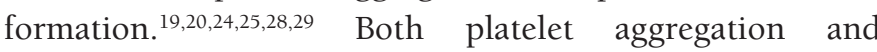
thrombus formation are essential for surgical hemostasis during primary hemostasis after the initial injury. ${ }^{36}$ In order to avoid any hemostatic problem in our study, we started $\mathrm{CaD}$ administration at post-operative $12^{\text {th }}$ hour. BPV has been used as a direct measure of the strength of CA. ${ }^{33}$ On the other hand, hydroxyproline is a part of collagen that was demonstrated to be positively correlated with the amount of collagen and healing of CA. ${ }^{9}$ Regardless of the administration method, both BPV and HV levels were significantly increased in the experimental groups that were treated with $\mathrm{CaD}(\mathrm{p}<0.05)$. This increase was much more evident when $\mathrm{CaD}$ dose was $100 / \mathrm{kg}$ per day $(\mathrm{p}<0.05)$. PNL is known as a potential source of collagenase in the wound healing site and is directly related to collagen catabolism. ${ }^{4}$ High collagenase activity plays an important role in anastomotic healing, causing low anastomotic strength early after the formation of an anastomosis because of collagen lysis. ${ }^{35}$ In our study, as there was decreased PNLS count and increased CFS accompanied by an increase in both BPV and HV in Groups 4 and 5 compared to Group 1, intraperitoneal administration of $100 / \mathrm{mg} / \mathrm{kg} \mathrm{CaD}$ per day was shown to have positive effect on CA healing. This result might be related to the expected consequences of antioxidant, neuroprotective, anti-inflammatory and capillary effects of $\mathrm{CaD}$. Neovascularization, which promotes collagen synthesis, enhances anastomotic strength. ${ }^{9}$ The decrease in VS levels at the given dose seems to be a disadvantage. However, a significant increase in BPV and $\mathrm{HV}$, and their positive effects on CA healing may be associated with suppression of overexpression by $\mathrm{CaD}$ on angiogenesis. ${ }^{22} \mathrm{CaD}$ was reported to exert aforementioned effect through VEGF and endothelin one. ${ }^{21,23} \mathrm{CaD}$ showed no anti-angiogenic effect when used as gavage at a dose of $100 \mathrm{mg} / \mathrm{kg}$ per day; this result may be related to excretion of $50 \%$ of the administrated drug via fecal material without any biotransformation. Further studies with higher doses of $\mathrm{CaD}$ application are needed to clarify the effects of gavage. In this study, when Group 1 and Group 2 were compared, no significant difference was observed in terms of BPV, HV and CFS ( $>>0.05)$. We also found the same findings when Group 4 and Group 5 were compared. These findings may be caused by a single daily dose of medication. Previous in vivo and in vitro studies have shown that repetitive $\mathrm{CaD}$ administrations within a day increase both antioxidant effect and lymphatic circulation. ${ }^{18,27,30}$ Administration of $\mathrm{CaD}$ at a dose of $50 \mathrm{mg} / \mathrm{kg} / \mathrm{day}$ was found to have no effect in PNLS. However, administration of $\mathrm{CaD}$ at a dose of $100 \mathrm{mg} / \mathrm{kg} /$ day reduced PNLS $(\mathrm{p}<0.05)$. This decrease was more prominent in Group 5 than in the other groups ( $\mathrm{p}<0.05)$. The decrease in MNLS was more prominent in the experimental groups than in the control group. The decrease in MNLS was more prominent in Group 4 ( $\mathrm{p}<0.05)$. Finally, with $\mathrm{CaD}$ administration at a dose of $100 \mathrm{mg} / \mathrm{kg} /$ day, both acute and chronic histopathological parameters of inflammation levels decreased significantly $(\mathrm{p}<0.05)$. In addition to the above, VS decreased when $\mathrm{CaD}$ was administered at a dose of $100 \mathrm{mg} / \mathrm{kg} / \mathrm{day}(\mathrm{p}<0.05)$. Moreover, $\mathrm{CaD}$ administration increased CFS in experimental groups $(p<0.05)$. The aforementioned effects of $\mathrm{CaD}$ (reducing 
capillary hyperpermeability and fragility by regulating capillary membrane resistance, enhancing plasticity and flexibility of thrombocytes, decreasing blood viscosity and increasing of blood fluidity, augmentation of lymphatic drainage and stimulation of lymph circulation, reducing protein-rich edema by increasing normal proteolysis, etc.) are known to be associated with macrophages and lymphatic transport. ${ }^{16,18,23,30,36}$ The decrease in serum protein levels (especially albumin) is critical for the healing of CA. A limitation of our study is the lack of biochemical parameters of blood such as albumin, and further studies are needed in this section.

\section{Conclusion}

To summarize, we found that $\mathrm{CaD}$ not only reduces pathological inflammation parameters, but also strengthens CA mechanically and biochemically. Although the decrease in neovascularization appears to have negative outcomes on $\mathrm{CA}$, we know that $\mathrm{CaD}$ inhibits over-expression in angiogenesis. Finally, these effects of CaD seemed to depend on the administration doses rather than the administration methods. Further researches are needed to clarify this topic.

\section{Ethics}

Ethics Committee Approval: Ethical protocol of the current research was approved by Ethics Committee of İstanbul University, İstanbul, Turkey. Institutional Review Board (IRB) (number: 2006/ 30826).

Informed Consent: Not applicable.

\section{Authorship Contributions}

Surgical and Medical Practices: S.D., S.D., Ö.S., G.B.D., H.U., Concept: S.D., S.D., Ö.S., G.B.D., H.U., T.İ., Design: S.D., S.D., Ö.S., G.B.D., H.U., T.İ., Data Collection or Processing: S.D., S.D., Ö.S., G.B.D., H.U., T.İ., Analysis or Interpretation: S.D., E.H., A.O., S.D., Ö.S., G.B.D., H.U., E.A., S.C.., A.T., Z.S., İ.T., T.İ., Literature Search: S.D., E.H., A.O., S.D., E.A., S.Ç., A.T., Z.S., İ.T., T.İ., Writing: S.D., E.H., A.O., S.D., E.A., S.C., A.T., Z.S., İ.T., T.İ.

Conflict of Interest: No conflict of interest was declared by the authors.

Financial Disclosure: The authors declared that this study received no financial support.

\section{References}

1. Ho YH, Ashour MA. Techniques for colorectal anastomosis. World J Gastroenterol 2010;16:1610-1621.

2. Koruda MJ, Rolandelli RH. Experimental studies on the healing of colonic anastomoses. J Surg Res 1990;48:504-515.

3. Ersoy YE. Effects of pentoxifylline and papaverine on anastomosis healing and clamp site perfusion in left colon anastomosis of the rats (experimental study). Thesis of Specialization of Medicine, Thesis Center,
Council of Higher Education. https://tez.yok.gov.tr/UlusalTezMerkezi/ tezSorguSonucYeni.jsp. Published 2003.

4. Hesp WL, Hendriks T, Schillings PH, Lubbers EJ, de Boer HH. Histological features of wound repair: a comparison between experimental ileal and colonic anastomoses. Br J Exp Pathol 1985;66:511-518.

5. Brasken P, Lehto M, Renvall S. Changes in the connective tissue composition of the submucosal layer of colonic anastomosis. An immunohistologic study in rats. Acta Chir Scand 1989;155:413-419.

6. Wise L, McAlister W, Stein T, Schuck P. Studies on the healing of anastomoses of small and large intestines. Surg Gynecol Obstet 1975;141:190-194.

7. Witte MB, Barbul A. Repair of full-thickness bowel injury. Crit Care Med 2003;31(8 Suppl):S538-546.

8. Podolsky DK. Review article: healing after inflammatory injury coordination of a regulatory peptide network. Aliment Pharmacol Ther 2000;14 Suppl 1:87-93.

9. Ferhatoğlu MF, Kıvılcım T, Vural G, Kartal A, Filiz Aİ, Kebudi A. Comparison of the effects of two different marine-derived omega-3 fatty acid sources, krill oil, and fish oil, on the healing of primary colonic anastomoses after colectomy applied Wistar albino rat model. Ulus Travma Acil Cerrahi Derg 2019;25:324-330.

10. Slieker JC, Daams F, Mulder IM, Jeekel J, Lange JF. Systematic Review of the Technique of Colorectal Anastomosis. JAMA Surg 2013;148:190-201.

11. Zhou S, Zhou H, Zheng Z, Liang J, Zhou Z, Wang X. Predictive risk factors for anastomotic leakage after anterior resection of rectal cancer in elderly patients over 80 years old: An analysis of 288 consecutive patients. World J Surg Oncol 2019;17:112.

12. Davis B, Rivadeneira DE. Complications of Colorectal Anastomoses: Leaks, Strictures, and Bleeding. Surg Clin North Am 2013;93:61-87.

13. Thornton FJ, Barbul A. Healing in the gastrointestinal tract. Surg Clin North Am 1997;77:549-573.

14. Binnebösel M, Grommes J, Koenen B, Junge K, Klink CD, Stumpf M, et al. Zinc deficiency impairs wound healing of colon anastomosis in rats. Int J Colorectal Dis 2010;25:251-257.

15. Lorenzi T, Trombettoni MMC, Ghiselli R, Paolinelli F, Gesuita R, Cirioni $\mathrm{O}$, et al. Effect of omiganan on colonic anastomosis healing in a rat model of peritonitis. Am J Transl Res 2017;9:3374-3386.

16. Arceo A, Berber A, Treviño C. Clinical evaluation of the efficacy and safety of calcium dobesilate in patients with chronic venous insufficiency of the lower limbs. Angiology 2002;53:539-544.

17. Seker A, Bardakci O, Eryilmaz S, Kocarslan S, Incebiyik A, Yucel Y, et al. Does calcium dobesilate protect against intestinal ischemia-reperfusion injury induced in rats? Eur Rev Med Pharmacol Sci 2016;20:2168-2173.

18. Piller N, Browning J. Effect of calcium dobesilate on the functional capabilities of mesenteric lymphatics in the guinea pig. Res Exp Med (Berl) 1986;186:167-172.

19. Suschek C, Kolb H, Kolb-Bachofen V. Dobesilate enhances endothelial nitric oxide synthase-activity in macro- and microvascular endothelial cells. Br J Pharmacol 1997;122:1502-1508.

20. Szlavy L, Repa I, Lengyel I, Lamboy L. Calcium dobesilate (CLS 2210) protects the myocardium in early acute myocardial infarction: A preliminary randomized, double-blind, placebo-controlled study of its effects on biochemical markers. J Cardiovasc Pharmacol 1990;15:89-95.

21. Solà-Adell C, Bogdanov P, Hernández C, Sampedro J, Valeri M, GarciaRamirez M, et al. Calcium Dobesilate Prevents Neurodegeneration and Vascular Leakage in Experimental Diabetes. Curr Eye Res 2017;42:12731286.

22. Lameynardie S, Chiavaroli C, Travo P, Garay RP, Parés-Herbuté N. Inhibition of choroidal angiogenesis by calcium dobesilate in normal Wistar and diabetic GK rats. Eur J Pharmacol 2005;510:149-156. 
23. Leal EC, Martins J, Voabil P, Liberal J, Chiavaroli C, Bauer J,et al. Calcium dobesilate inhibits the alterations in tight junction proteins and leukocyte adhesion to retinal endothelial cells induced by diabetes. Diabetes 2010;59:2637-2645.

24. Cortelekoglu T, Bozkurt AK, Ustundag N, Koksal C, Sayin AG. The effects of clopidogrel and calcium dobesilate on intimal hyperplasia following vascular injury. Acta Chir Belg 2006;106:206-210.

25. Tamás P, Csermely T, Ertl T, Vizer M, Szabó I, Prievara FT. Calcium dobesilate lowers the blood pressure in mild to moderate midtrimester hypertension. A pilot study. Gynecol Obstet Invest 1999;47:210-213.

26. Jafarey M, Changizi Ashtiyani S, Najafi H. Calcium dobesilate for prevention of gentamicin-induced nephrotoxicity in rats. Iran J Kidney Dis 2014;8:46-52.

27. Brunet J, Farine JC, Garay RP, Hannaert P. Angioprotective action of calcium dobesilate against reactive oxygen species-induced capillary permeability in the rat. Eur J Pharmacol 1998;358:213-220.

28. Martínez-Zapata MJ, Moreno RM, Gich I, Urrútia G, Bonfill X; Chronic Venous Insufficiency Study Group. A Randomized, Double-Blind Multicentre Clinical Trial Comparing the Efficacy of Calcium Dobesilate with Placebo in the Treatment of Chronic Venous Disease. Eur J Vasc Endovasc Surg 2008;35:358-365.

29. Wollina U, Abdel-Naser MB, Mani R. A review of the microcirculation in skin in patients with chronic venous insufficiency: The problem and the evidence available for therapeutic options. Int J Low Extrem Wounds 2006;5:169-180.

30. Piller NB. The lymphogogue action of calcium dobesilate on the flow of lymph from the thoracic duct of anesthetized and mobile guinea pigs. Lymphology 1988;21:124-127.

31. Yilmaz HG, Odabaşi M, Büyükbayram H, Baç B. Effectiveness of fibrin tissue adhesive for colocolic anastomosis reliability. Ulus Travma Derg 2001;7:87-90.

32. Cissell DD, Link JM, Hu JC, Athanasiou KA. A Modified Hydroxyproline Assay Based on Hydrochloric Acid in Ehrlich's Solution Accurately Measures Tissue Collagen Content. Tissue Eng Part C Methods 2017;23:243-250.

33. Jansen-Winkeln B, Tagkalos E, Heimann A, Gaiser T, Hirsch D, Gockel I, et al. Pringle maneuver increases the risk of anastomotic leakage after colonic resection in rats. HPB (Oxford) 2018;20:392-397.

34. Despoudi K, Mantzoros I, Ioannidis O, Cheva A, Antoniou N, Konstantaras D, et al. Effects of albumin/glutaraldehyde glue on healing of colonic anastomosis in rats. World J Gastroenterol 2017;23:5680-5691.

35. Costales AB, PatilD, Mulya A, KirwanJP, Michener CM. 2-Octylcyanoacrylate for the prevention of anastomotic leak. J Surg Res 2018;226:166-172.

36. Menteş BB, Görgül A, Tatlicioğlu E, Ayoğlu F, Unal S. Efficacy of calcium dobesilate in treating acute attacks of hemorrhoidal disease. Dis Colon Rectum 2001;44:1489-1495. 